\title{
Capital Expenditure and Natural Risk Incentives Analysis for the Hotel Industry In Padang
}

\author{
Masyhuri Hamidi ${ }^{1}$ and Fajri Adrianto ${ }^{2}$ \\ \{masyhurihamidi@eb.unand.ac.id ${ }^{1}$, fajri.adrianto@hotmail.com ${ }^{2}$ \} \\ Economic Faculty, Andalas University, Jl. Universitas Andalas, Limau Manis, Pauh, West Sumatra \\ 25163, Padang, Indonesia ${ }^{1}$; \\ Management Department, Economic Faculty, Andalas University, Jl. Universitas Andalas, Limau \\ Manis, Pauh, West Sumatra 25163, Padang, Indonesia ${ }^{2}$
}

\begin{abstract}
This study is aiming at studying the factors that will influence the capital expenditure decision for Hotel businesses in Padang, where there is a high natural environment risk specifically the earthquake and tsunami. By asking several hotels ranging from two star up to four star hotels, this study have found that location decision does not affect the risk on investment for the hotel in Padang City. The factor that does have influence on the investment is the inflows activity from the tourism in Padang. The high potential of inflow in the tourism sector can cover the capital cost and risk that have been taken by the investor. The support from financial organization in helping with the capital is also the factor that are being considered in the hotel industry in Padang because the higher the supply of financial helps can also decrease the cost of capital.
\end{abstract}

Keywords: capital expenditure decision, natural risk.

\section{Introduction}

The decision on capital expenditure in a company is very important because it can affect a company performance. McConnell and Muscarella [1] stated that capital expenditure has a direct influence on a company performance. If a mistake has been made in deciding on the capital expenditure, there will be a long term impact on the company, since investments in capital expenditures are usually invested for long-term fixed asset. Therefore, the selection of capital expenditures in the hotel industry will affect the profits of the company which will also affect the prosperity of shareholders or owners.

The hotel industry is one of the most popular industry in the Western Sumatera Province which has a relatively high market growth. Though with the high rate of earthquake, but still many new hotels are being built. This phenomena has become the indicator for the hotel industry where there are a lot of investor are interested to invest in the project. This is also supported by a rapid growth of tourism in West Sumatera, where the number of local and international tourists increase every year.

Based on the data in table 1 above, it can be seen that the number of hotels increased in the period 2013 - 2014. Furthermore, from the 370 hotels in Western Sumatera in 2014, 60 of the hotels are starred hotels and 33 of the starred hotels are located in Padang, 17 hotels in Bukittinggi, one hotel in Sawah Lunto, and the remaining is in Padang Panjang. 
Over the past few years, the hospitality industry has invested heavily in capital expenditures to improve customer services such as; flat screen television, fast internet access, beautify room, lobby and restaurant. These capital expenditures are long-term and require substantial funds with sufficiently risky funding sources such as using long-term debt [2].

Table 1 Total Hotel in the West Sumatera Province in 2013 - 2014

\begin{tabular}{|r|r|r|r|r|}
\hline & \multicolumn{2}{|c|}{ Hotel } & \multicolumn{2}{c|}{ Rooms } \\
\hline Year & 2013 & 2014 & 2013 & 2014 \\
\hline Total & 339 & 370 & 7794 & 8321 \\
\hline
\end{tabular}

Source: West Sumatera in 2015

This phenomenon is different from the investment literature where the area with high natural risk tends to decrease the level of investment [3]. Natural risks tend to be avoided by some investors for reasons of potential damage, impairment and asset damage. As for the securing the value of the assets with the use of insurance, the price for location with higher natural risk tends to be higher than the location with lower risk. Consequently, the total investment will increase. Natural risk is not only contained in the beta of project used in the calculation of equity costs but also has been included in the cost of debt where lenders have included this risk component in the debt risk.

With the limited resources, hotel management are facing problems in investment budget priorities and balancing profits with risks in increasing shareholder wealth. The challenge for hotel managers is to ensure that any capital expenditure decisions are not likely to be inefficient in the company's operations. Failure to invest in capital expenditures can result in a loss of market share because of the inability to offer the level of consumer desire of quality services at an attractive price. Therefore, it is crucial to identify the optimal capacity or capacity thresholds that describe the critical level requires to support service activities [4].

To make capital expenditure decisions, company managers typically use some capital budgeting techniques such as payback period (PP), net present value (NPV), internal rate of return (IRR), profitability index (PI) and accounting rate of return (ARR). Based on a survey of companies listed on the Fortune 1000 list, the NPV results is the most preferred capital budgeting technique by financial managers. This study also find that the financial managers use some capital budgeting techniques in investment analysis.

In the NPV calculation, each investment project has a required return or capital cost that is an incentive of the risk taken from the project. For business hotels in areas that have great natural disaster potential such as Padang, this natural risk has been included in the calculation of the cost of capital. This research will be conducted on identifying the incentives from natural risk incentives of capital expenditures made by hotels in Padang City, as well as the components of the natural risk that are considered when making a business feasibility analysis.

Based on the above explanation, the phenomenon of capital expenditure in the hotel industry in Padang City, is an important research object to be studied. Throughout our knowledge, research on natural risk-taking incentives has not been widely implemented, particularly those related to earthquake and tsunami risk. The formulation of the problem disclosed in this research are:

1 What are the factors that influence the decision of capital expenditure on the hotel industry in Padang City?

2 How is the effect of natural risk on hotel business incentives in Padang city? 


\section{Literature Review}

Capital expenditure decisions and firm performance have a positive relationship [1], this means that firm performance is largely determined by decisions and the amount of funds in corporate capital expenditures. Then Gitman \& Zutter [5] state that capital expenditures by firms are driven by several motives: business expansion, replacing of fixed assets and other reasons that have long-term benefits.

The determinants of capital expenditure according to Sartono [6] are Internal Cash Flow and Insider Ownership, where the greater the internal cash flow of the company, the greater the capital expenditure of the company, the greater the insider ownership, the less capital expenditure will be because the management tends to be more cautious in capital expenditures because if there is a mistake in the decision making, the management will also responsible for the risk.

Griner and Gordon [7] explains that capital expenditure is the amount of investment in property, plant and equipment (PPE). Collier \& Gregory [8] adopted a field study approach to examine the practice of capital budgeting in the hotel sector. Their study found the fact that the hospitality business is highly capital-intensive.

Olsen et.al. [9] states that there are 5 major forces driving the changes that will affect the tourism industry within this new millennium. The intended strength is; capacity control, safety and security, assets and capital, technology, and new management. To date, almost all of these five major powers are the drivers of change in the industry, we can see them either through positive or negative implications.

Over the past few years, the hotel industry has invested a large amount of expenses to improve guest facilities and services including flat-screen televisions, high-speed internet access and redesign of guest rooms, lobby and restaurants. However, the Internet has changed the way business operates; accommodation companies began to employ ICTs to improve their daily operations and control their assets [10]. The Internet also plays an important role of mediation between customers and hotel companies as a place for information acquisition and business transactions [11].

This capital expenditure is long-term in nature and in large amounts of money from risky financial resources. With limited resources, managers must be able to overcome challenges to ensure that any capital expenditure decisions do not lead to operational inefficiency. Failure to invest in capital expenditures may result in the loss of market share due to the inability to offer the desired level of service quality at attractive prices.

Hotels generally bear large expenses and these are classified into two categories. The first group is called revenue expenses related to the profits realized within a year. This cost is also known as the period cost. Period cost is deducted from annual revenue in the same accounting period when costs occur. Thus, revenue expenditure reduces the taxable income for the year. The second group of expenditures is classified as capital expenditure and its profits are extended for more than one year [12]. Such expenditures include expenditures incurred to purchase long-term assets such as land, buildings and equipment or commonly referred to as Fixed Assets (PPE).

Research conducted by Kim [13] at a manufacturing company in Korea (1991-1998) investigated the impact of family ownership in capital structure on firm performance. The findings show that a positive relationship between the two variables indicates that the higher the family ownership in the firm's capital structure the firm's performance will increase. Maury [14] also found increased performance due to family ownership in Western European companies. Specifically stated that family ownership plays an important role in improving the 
profitability of the company. This shows that family ownership decreases the classical agency problem between manager and owner.

In the Malaysian context, where government ownership and institutional ownership are relatively high, the impact of ownership on business decisions can be set aside. Fraser et. al., [15] found that firms with high government ownership and institutional ownership are generally profitable and have high leverage. Pecking Order Hypothesis (POH) states that there is no conflict between managers and current shareholders and thus, there is no influence between capital expenditure and insider ownership. Conversely, Managerial Hypothesis (MH) argues that managers increase their interest in determining the level of capital expenditure. Low managerial ownership can provide incentives for them to make higher capital expenditures. In other words, increasing insider ownership is expected to reduce managerial over-investment in capital expenditures. Thus, Managerial Hypothesis predicts an inverse relationship between capital expenditure and insider ownership.

Recently, a study by Dalbor \& Jiang [16], using samples from the US restaurant industry in 2002 through 2012 examining how internal cash flow affects the company's capital expenditure. Their study found that internal cash flow and firm size are a positive determinant of capital expenditure, while economic recession is a negative determinant of capital expenditure.

According to the International Society of Hospitality Consultants [17], variations in the classification of capital expenditures are mainly due to the flexibility of its definition. For example, KPMG does not include new hotels built in the definition of capital expenditures [18]. Only items recorded in the balance sheet as fixed assets are included as capital expenditures. On the other hand, the study of the International Society of Hospitality Consultants [17] reports that capital expenditures also include capital improvement costs that extend the asset's economic life span.

According to Brignall [19], about 75 percent of the total hotel cost is fixed. The cost per square meter of hotel room can reach $£ 1,300$ or $£ 13,600,000$ for a hotel that has 150 rooms [20]. Comparing small firms with large companies, Barclay \& Smith (1995) suggest that large firms are able to make and pay a higher fixed cost of debt and thus, will result in higher debt levels. In addition, Sheel [21] argues that large corporations also enjoy lower debt costs because the size of the firm is associated with the low probability of the company going bankrupt.

The Capex 2007 study conducted by the International Society of Hospitality Consultants (ISCH) [17], a review of capital expenditures in the hotel industry, found trends and historical capital outlays. The study is conducted in the United States and covers only the full service hotel / luxury hotel type, selected hotel services and extended stay hotel customers. This study has several significant findings that can be used as a reference and lesson to understand the domain of capital expenditures by the hospitality industry, namely:

- Capital expenditures for hotels are increasing according to the age of the hotel. Capital expenditures can be significant in the early years of a new hotel and increase dramatically from one year to the next.

- Percentage of repair and maintenance will increase according to the income and age of the hotel, exceptions when the property is fully renovated and or repositioned. The hotels analysed in this study indicate that spending is fairly consistent in repairs and maintenance over the life of the asset. The percentage of expenditure from total revenues ranged from 34.5 percent. 
- On a long-term basis, CapEx 2007 data shows that all hotels, from new hotels to old / old hotels, spend an average of 8.5-9.8 percent of total revenues on capital expenditures for repairs and maintenance.

- From a historical perspective, the CapEx 2007 survey reveals that an overall decrease in capital expenditure from previous studies for hotels owned by public companies. Conversely, privately owned hotels show an increase in capital expenditures.

- The CapEx 2007 Survey revealed that capital expenditure as a percentage of total hotel revenues owned by public companies exceeds expenditures for private property.

- In full service type hotels and extended stay properties, private hotel-owned shopping is analysed as a ratio of total revenue and per room available higher than hotel expenses owned by a public company.

\section{Research Method}

This research will use qualitative and quantitative methods. For that purpose, a survey questionnaire (survey questioner), semi-structured interviews to the CEO (Chief Financial Officer) and / or CFO (Chief Financial Officer) of the hotel were sampled. Quantitative methods are used to test models that explain factors affecting capital expenditure decisions in the hospitality industry, incentives from natural risk taking and natural risk components to be considered in calculating the capital cost of the hospitality industry in Padang city.

The population of this study were all hotels that stood after the Padang city earthquake of 2009. The sample of this study is a 2 to 5 star hotel and the interview will be focused on gathering information about the practice of capital expenditure decision making. According to Ryan et al. [22], there are 5 types of field research or interview namely; descriptive, illustrative, experimental, exploratory, and explanatory. This field research study uses exploratory type because the interview will be focused to determine the issues related to capital investment decisions. Then, the sample technique used is purposive sampling which is to determine the number of samples to be used in this study so that in accordance with the targeted, by choosing the location / city in the city of Padang.

\section{Result and Discussion}

\subsection{Respondent Characteristics}

Research does not limit the characteristics of hotels in determining the sample. The questionnaires were disseminated and interviews were also conducted to get more in-depth information on what factors were considered by the hotel industry when deciding to develop new investment in hotel business in Padang city. From the graph 1, it can be seen that the majority of the respondent are managers from the star one and two hotels, while only 20 percent of the respondent are from the three star hotel. While for the four star hotel, it is relatively difficult to obtain the data from the managers. 


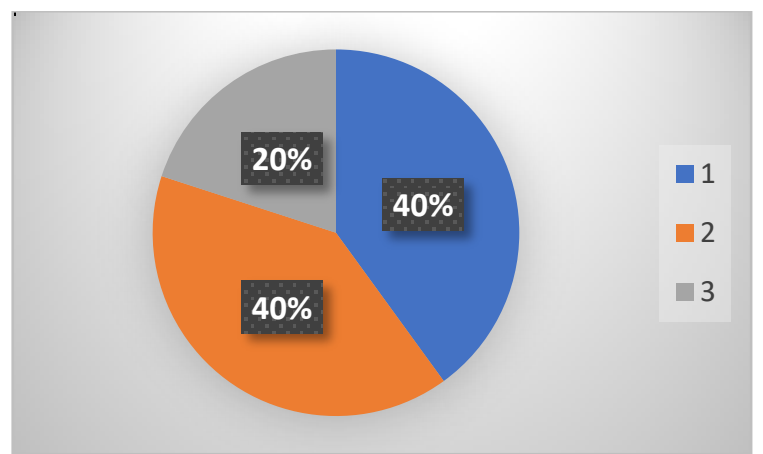

Figure 1 Characteristic of Respondent According to the Hotel Star

Characteristics of respondents cannot be developed further in order to facilitate data access to the executive of the hotel because some of the identity data of respondents and hotels are confidential, so this research focuses on only a few characteristics. For example, in Table 2, this study attempts to identify the site factor by asking the distance of the hotel building to the beach. So far this issue has become very important because it deals with disaster issues especially the tsunami disaster. For 40 percent of the respondent, their hotel location from beach are very close which is less than half a kilometre. Approximately 40 percent more are located relatively far from the beach, which is more than 5 kilometres.

Table 2 Respondent Characteristic

\begin{tabular}{lc}
\hline Characteristic & Percentage \\
\hline Distance from the shoreline & \\
Less than 500 meters & $40 \%$ \\
1-2 meters & $20 \%$ \\
Over 5 kilometres & $40 \%$ \\
& \\
Established & \\
Before 2009 & $40 \%$ \\
After 2009 & $60 \%$ \\
\hline
\end{tabular}

The majority of the hotels in this research only established after the 2009 earthquake, about 60 percent. The remaining $40 \%$ have stood before the 2009 earthquake. But of the 40 percent who stood before the 2009 earthquake, almost all of them made significant investment development after the earthquake.

\subsection{The Influence of Site Factor to Investment Decision}

In investing, site selection becomes very important because it does not only deals with future cash flows from planned investments, but also deals with investment risks. For investments in 
the city of Padang with higher natural risk potential, particularly from earthquake and tsunami risk, proper location selection is essential to predict future potential disaster losses.

Table 3 Site Factor in the Decision of Hotel Location

\begin{tabular}{cr}
\hline & Percentage \\
\hline Risk: Distance to Shoreline & \\
Strongly Disagree & $20 \%$ \\
Disagree & $40 \%$ \\
Neutral & $40 \%$ \\
Agree & $0 \%$ \\
Strongly Agree & $0 \%$
\end{tabular}

Closeness to Damaged

Buildings

$\begin{array}{lr}\text { Strongly Disagree } & 20 \% \\ \text { Disagree } & 60 \% \\ \text { Neutral } & 20 \% \\ \text { Agree } & 0 \% \\ \text { Strongly Agree } & 0 \%\end{array}$

Current Location According to

Natural Risk

Strongly Disagree $\quad 20 \%$

Disagree $20 \%$

Neutral $20 \%$

Agree $\quad 40 \%$

Strongly Agree $\quad 0 \%$

Table 3 shows that the proximity of the hotel's location to the beach is not a major component in determining investment risk. About 60 percent of respondents say that they were not affected by the proximity factor with the beach in site selection, although the potential risks for tsunami were greater. Locations adjacent to buildings destroyed by the 2009 earthquake are also not factors considered in determining hotel business risk in Padang city. 80 percent of respondents stated strongly disagree and disagreed with the statement that proximity to buildings affected by the 2009 earthquake became a moral hazard for the risk of losses due to earthquakes. However, for 40 percent of respondents, the current risk selection is based on an analysis of possible natural risks in the city of Padang.

\subsection{Factor of Earthquake / Tsunami}

The probability of occurrence of natural disasters, especially earthquakes that will occur in the city of Padang. Based on table 4, 40 percent of respondents agreed that the potential or issue of the earthquake could decrease the asset or the fixed assets of the hotel. But 60 percent said they disagreed with the statement. 
Table 4 Perception to natural Disasters

\begin{tabular}{lr}
\hline & Percentage \\
\hline Potential of Decreasing Assets Value & $20 \%$ \\
Strongly Disagree & $40 \%$ \\
Disagree & $0 \%$ \\
Neutral & $40 \%$ \\
Agree & $0 \%$ \\
Strongly Agree & \\
& \\
Earthquake Frequency Becomes an Important Factor & $0 \%$ \\
Strongly Disagree & $60 \%$ \\
Disagree & $0 \%$ \\
Neutral & $40 \%$ \\
Agree & $0 \%$ \\
Strongly Agree & \\
& \\
Probability of a Bigger Earthquake & $0 \%$ \\
Strongly Disagree & $40 \%$ \\
Disagree & $0 \%$ \\
Neutral & $60 \%$ \\
Agree & $0 \%$ \\
Strongly Agree & \\
&
\end{tabular}

The same result was also obtained for the effects of earthquake frequency on the earthquake decision. There are 60 percent of respondents said the frequency of the earthquake is not an important factor in making investment decisions in the city of Padang. However, the majority of respondents agreed that the probability of an earthquake in the city is greater than in other cities in Indonesia. Although not a major factor considered in making investment decisions in the city of Padang, their concern for the earthquake disaster is relatively higher.

\subsection{Perspective of Respondents to Tourism in Padang City}

Having previously focused on potential cash outflows due to potential risks from natural disasters, it is necessary to analyse the potential for cash inflows, especially the potential occupancy rate of rooms and the use of non-room facilities. Table 5 shows the responses of respondents about the potential cash inflows from the tourism sector and events held in the city of Padang.

Table 5 Perception of Potential Cash Inflow from Tourism Sector

\begin{tabular}{cr}
\hline & Percentage \\
\hline Optimism on Tourists Visitor & \\
Strongly Disagree & $0 \%$ \\
Disagree & $0 \%$ \\
Neutral & $0 \%$ \\
Agree & $60 \%$ \\
Strongly Agree & $40 \%$ \\
\hline
\end{tabular}


Positive Impact from Government

Campaign

Strongly Disagree $\quad 0 \%$

Disagree 20\%

Neutral $\quad 0 \%$

Agree $\quad 60 \%$

Strongly Agree $20 \%$

International Event: Increase Rate of Occupancy

$\begin{array}{lr}\text { Strongly Disagree } & 0 \% \\ \text { Disagree } & 0 \% \\ \text { Neutral } & 0 \% \\ \text { Agree } & 60 \% \\ \text { Strongly Agree } & 40 \%\end{array}$

International Event: Increase of Non-Room Business

Strongly Disagree $\quad 0 \%$

Disagree $\quad 0 \%$

Neutral $\quad 0 \%$

Agree $\quad 60 \%$

Strongly Agree $\quad 40 \%$

National Event: Increase Rate of

Occupancy

Strongly Disagree $\quad 0 \%$

Disagree $\quad 0 \%$

Neutral $\quad 0 \%$

Agree $\quad 60 \%$

Strongly Agree $\quad 40 \%$

National Event: Increase of Non-

Room Business

Strongly Disagree $\quad 0 \%$

Disagree $\quad 0 \%$

Neutral $\quad 0 \%$

Agree $\quad 40 \%$

Strongly Agree $\quad 60 \%$

Local Event: Increase Rate of

Occupancy

Strongly Disagree $\quad 0 \%$

Disagree $\quad 0 \%$




\begin{tabular}{lr}
\hline & Percentage \\
\hline Neutral & $20 \%$ \\
Agree & $60 \%$ \\
Strongly Agree & $20 \%$
\end{tabular}

Local Event: Increase of Non-Room Business

Strongly Disagree $\quad 0 \%$

Disagree $20 \%$

Neutral $20 \%$

Agree $\quad 40 \%$

Strongly Agree $\quad 20 \%$

Table 5 shows the optimism of hotels to the cash inflows from tourism activities in the city of Padang. Although there are issues of earthquake and tsunami, respondents are optimistic that the level of tourist visits in the city of Padang will continue to increase. The majority of respondents also believe that tourism campaigns conducted by local and central government will have an impact on the increase of local and foreign tourist visits to the city of Padang, so as to increase hotel revenues in the city of Padang. Only 20 respondents did not agree that the campaign will have a positive impact on tourism in the city of Padang.

Table 6 Investment Capital Cost in Padang City

\begin{tabular}{lr}
\hline & Percentage \\
\hline Beta of Padang City is Bigger Than \\
the Neighbouring City \\
Strongly Disagree & $0 \%$ \\
Disagree & $0 \%$ \\
Neutral & $80 \%$ \\
Agree & $20 \%$ \\
Strongly Agree & $0 \%$ \\
& \\
Beta of Padang City is Bigger Than & \\
the City Outside of West Sumatra & \\
Strongly Disagree & $0 \%$ \\
Disagree & $0 \%$ \\
Neutral & $80 \%$ \\
Agree & $20 \%$ \\
Strongly Agree & $0 \%$ \\
& \\
Required Return in Padang City is & \\
Higher than the Neighbouring City & \\
Strongly Disagree & $20 \%$ \\
Disagree & $20 \%$ \\
Neutral &
\end{tabular}




\begin{tabular}{|c|c|}
\hline & Percentage \\
\hline Agree & $60 \%$ \\
\hline Strongly Agree & $0 \%$ \\
\hline \multicolumn{2}{|c|}{ Required Return in Padang City is } \\
\hline \multicolumn{2}{|l|}{ Higher than the City Outside of } \\
\hline \multicolumn{2}{|l|}{ West Sumatra } \\
\hline Strongly Disagree & $0 \%$ \\
\hline Disagree & $20 \%$ \\
\hline Neutral & $60 \%$ \\
\hline Agree & $20 \%$ \\
\hline Strongly Agree & $0 \%$ \\
\hline \multicolumn{2}{|l|}{ Requires Return in Padang } \\
\hline \multicolumn{2}{|l|}{ Including Natural Risk } \\
\hline Strongly Disagree & $0 \%$ \\
\hline Disagree & $20 \%$ \\
\hline Neutral & $60 \%$ \\
\hline Agree & $20 \%$ \\
\hline Strongly Agree & $0 \%$ \\
\hline \multicolumn{2}{|l|}{ Requires Return in Padang } \\
\hline \multicolumn{2}{|l|}{ Including Natural Risk } \\
\hline Strongly Disagree & $0 \%$ \\
\hline Disagree & $0 \%$ \\
\hline Neutral & $100 \%$ \\
\hline Agree & $0 \%$ \\
\hline Strongly Agree & $0 \%$ \\
\hline \multicolumn{2}{|c|}{$\begin{array}{l}\text { Anti-Seismic Technology Lowers } \\
\text { the Cost of Capital }\end{array}$} \\
\hline Strongly Disagree & $0 \%$ \\
\hline Disagree & $60 \%$ \\
\hline Neutral & $20 \%$ \\
\hline Agree & $20 \%$ \\
\hline Strongly Agree & $0 \%$ \\
\hline
\end{tabular}

For events held in the city of Padang, respondents believe that the events will give cash flow for the hotel business in Padang city. Especially international and national events, benefits are not only obtained from the occupancy rate of the rooms, but also from non-room revenue such as rental of premises such as hall and other facilities.

For local events, about 40 percent of respondents said they did not know or disagreed if the local event had a positive impact on the hotel's revenue from non-chamber business. 


\subsection{Investment Capital Cost in Padang City}

In calculating capital costs, the determination of market risk (Beta) and required returns (cost of capital) is very important to avoid acceptance of projects that should have negative NPV or reject investments that should have a positive NPV. Table 6, the majority of respondents do not want to answer how many betas they use with the majority answered do not know. Some respondents stated that information about the beta is relatively secretive or some hotel voters never use the beta as a basis in decision makers. Only 20 percent of respondents stated that Beta investment in Padang city is bigger compared to other cities especially with cities that are not in the earthquake area.

But actually the total risk of investment can be seen from the required return used when the preparation of capital budgeting. Compared with neighbouring cities such as Jambi and Pekanbaru, the required return used in Padang is relatively larger. 60 percent stated that the required return in the city of Padang is greater with neighbouring cities. This indicates that additional risk has been included in the capital cost calculation.

\subsection{Financing and Insurance Institution Support}

Supports from financing institutions such as Banks and Insurance become very important in making investment decisions. The availability of financing facilities from banks with lower costs will be able to lower the cost of capital investment plan so that the potential feasibility of an investment in the city of Padang will be greater. From table 4.6 can be seen that there is a good support from the bank in financing the hotel investment in the city of Padang. This can be shown by the $60 \%$ of respondents agreed that the access to bank financing is relatively easy. While the majority of respondents do not know whether the interest rate of capital loans provided by banks for investment in the city of Padang are larger or smaller than the investment in other cities. The same is also answered by respondents to the minimum credit limit provided by the bank, whereas the average respondent does not know whether the credit limit provided by the banking for investment in Padang city is bigger or smaller than other cities

Table 7 Financing and Insurance Institution Support

\begin{tabular}{cc}
\hline & Percentage \\
\hline $\begin{array}{l}\text { Easier access of capital through } \\
\text { bank loans }\end{array}$ \\
Strongly Disagree & $0 \%$ \\
Disagree & $20 \%$ \\
Neutral & $20 \%$ \\
Agree & $60 \%$ \\
Strongly Agree & $0 \%$ \\
& \\
Higher interest rate in Padang & \\
Strongly Disagree & $0 \%$ \\
Disagree & $20 \%$ \\
Neutral & $60 \%$ \\
Agree & $20 \%$ \\
\hline
\end{tabular}




\begin{tabular}{|c|c|}
\hline & Percentage \\
\hline Strongly Agree & $0 \%$ \\
\hline \multicolumn{2}{|c|}{$\begin{array}{l}\text { Lower minimum limit of capital } \\
\text { loan }\end{array}$} \\
\hline Strongly Disagree & $0 \%$ \\
\hline Disagree & $20 \%$ \\
\hline Neutral & $60 \%$ \\
\hline Agree & $20 \%$ \\
\hline Strongly Agree & $0 \%$ \\
\hline \multicolumn{2}{|c|}{$\begin{array}{l}\text { Easy to find insurance due to high } \\
\text { natural risk }\end{array}$} \\
\hline Strongly Disagree & $0 \%$ \\
\hline Disagree & $40 \%$ \\
\hline Neutral & $20 \%$ \\
\hline Agree & $40 \%$ \\
\hline Strongly Agree & $0 \%$ \\
\hline \multicolumn{2}{|c|}{$\begin{array}{c}\text { Insurance premiums are higher in } \\
\text { Padang city }\end{array}$} \\
\hline Strongly Disagree & $0 \%$ \\
\hline Disagree & $20 \%$ \\
\hline Neutral & $60 \%$ \\
\hline Agree & $20 \%$ \\
\hline Strongly Agree & $0 \%$ \\
\hline
\end{tabular}

For the value of earthquake and tsunami risk, 40 percent of respondents stated that it is easy to get insurance that will guarantee losses due to earthquake and tsunami disaster. Yet another 40 percent said they disagreed if they could get an insurance company that would guarantee the loss of natural disasters because the probability of earthquake occurrence in the city of Padang is relatively large. Even if there are insurance companies that provide these guarantees, the premium set tends to be greater. But the majority of respondents actually do not know whether the premium is expensive or not. For those premiums offered can still be affordable.

\section{Conclusion}

This research tries to examine the factors that determine the capital expenditure in Padang city for hotel business. By using descriptive qualitative research method, this research concludes several things as follows: (1) Site factor is not an important factor in investment decisions made by hotel business in Padang city. The location of the hotel that is near or further from the coastline is not a major factor in determining business risk. (2) The potential inflows of tourism activities and events that are local, national and international become a crucial factor why business hotels in the city of Padang is still very attractive after the earthquake in 2009. (3) Beta or market risk is not a major concern for business players in the 
preparation of capital budgeting because of all the risks. (4) Support and convenience provided by financing institutions such as banking and the availability of insurance as a hedge of investment assets is a factor considered in investment decisions. (5) Risks taken by hotel owners are getting incentives in the form of potential inflows of tourism activities and events and support from banks that can make the cost of capital becomes relatively cheaper.

\section{Research Implication}

The several literature and managerial implications of this research are as follows: (1) this study reinforces the literature on the cost of capital that tends to be greater for investments with greater natural risk. (2) The results of this study also support the financial literature on the importance of greater supply of funds to reduce capital costs. (3) In managerial perspective, the results of this study have implications for the importance of government policies and efforts in intensifying tourist visits to the city of Padang because the main factors considered business hotels in the city of Padang is the visit of tourists and events. (4) The government can cooperate with financial institutions by providing guarantee for capital investment into Padang city so that the cost of capital can become smaller.

\section{References}

[1] J. J. McConnell and C. J. Muscarella, "Corporate capital expenditure decisions and the market value of the firm," J. financ. econ., vol. 14, no. 3, pp. 399-422, 1985.

[2] F. Galizia and D. O’Brien, "Do capital expenditures determine debt issues?," Economic and Financial Report, 2001.

[3] I. Schumacher and E. Strobl, "Economic development and losses due to natural disasters: The role of hazard exposure," Ecol. Econ., vol. 72, pp. 97-105, 2011.

[4] A. Saveriades, "Establishing the social tourism carrying capacity for the tourist resorts of the east coast of the Republic of Cyprus," Tour. Manag., vol. 21, no. 2, pp. 147-156, 2000.

[5] C. J. Zutter and L. J. Gitman, Principles of Managerial Finance, 12th ed. Pearson Education Limited, 2012.

[6] A. Sartono, "Pengaruh Aliran Kas Internal Dan Kepemilikan Manajer Dalam Perusahaan Terhadap Pembelanjaan Modal: Managerial Hypotheses Atau Pecking Order Hypotheses? 1," J. Indones. Econ. Bus., vol. 16, no. 1, 2001.

[7] E. H. Griner and L. A. Gordon, "Internal cash flow, insider ownership, and capital expenditures: a test of the pecking order and managerial hypotheses," J. Bus. Financ. Account., vol. 22, no. 2, pp. 179-199, 1995 .

[8] P. Collier and A. Gregory, "Strategic management accounting: a UK hotel sector case study," Int. J. Contemp. Hosp. Manag., vol. 7, no. 1, pp. 16-21, 1995.

[9] M. D. Olsen, T. Ching-Yick, and J. J. West, Strategic management in the hospitality industry., no. Ed. 2. John Wiley and Sons, 1998.

[10] D. Buhalis, eTourism: Information technology for strategic tourism management. Pearson education, 2003.

[11] K. Liang and R. Law, "A modified functionality performance evaluation model for evaluating the performance of China based hotel websites," J. Acad. Bus. Econ., 2003.

[12] W. P. Andrew, R. S. Schmidgall, and J. W. Damitio, Financial management for the hospitality industry. Pearson Prentice Hall Upper Saddle River, NJ, 2007.

[13] E. Kim, "The impact of family ownership and capital structures on productivity performance of Korean manufacturing firms: Corporate governance and the "chaebol problem," J. Jpn. Int. 
Econ., vol. 20, no. 2, pp. 209-233, 2006.

[14] B. Maury, "Family ownership and firm performance: Empirical evidence from Western European corporations," J. Corp. Financ., vol. 12, no. 2, pp. 321-341, 2006.

[15] D. R. Fraser, H. Zhang, and C. Derashid, "Capital structure and political patronage: The case of Malaysia," J. Bank. Financ., vol. 30, no. 4, pp. 1291-1308, 2006.

[16] M. Dalbor and L. Jiang, "Determinants of capital expenditures in the US restaurant industry," $J$. Hosp. Financ. Manag., vol. 21, no. 2, pp. 77-86, 2013.

[17] S. Mellen, K. Nylen, and R. Pastorino, Capex 2000: A study of capital expenditures in the US hotel industry. International Society of Hospitality Consultants, 2000.

[18] KPMG, "Capital Expenditure: A Survey of UK Hotels -1998, London," London, 1999.

[19] S. Brignall, "A contingent rationale for cost system design in services," Manag. Account. Res., vol. 8, no. 3, pp. 325-346, 1997.

[20] J. Ransley and H. Ingram, "What is 'good' hotel design?," Facilities, vol. 19, no. 1/2, pp. 7987,2001

[21] A. Sheel, "Determinants of capital structure choice and empirics on leverage behavior: A comparative analysis of hotel and manufacturing firms," Hosp. Res. J., vol. 17, no. 3, pp. 1-16, 1994.

[22] B. Ryan, R. W. Scapens, and M. Theobald, Research Method and Methodology in Finance and Accounting. London: Academic Press, 1992. 